\title{
A resistant-starch enriched yogurt: fermentability, sensory characteristics, and a pilot study in children [version 1; peer
}

\section{review: 2 approved]}

\author{
Kayanush Aryana1,2, Frank Greenway², Nikhil Dhurandhar ${ }^{3}$, Richard Tulley4, \\ John Finley ${ }^{4}$, Michael Keenan, ${ }^{4}$ Roy Martin ${ }^{5}$, Christine Pelkman6, Douglas Olson', \\ Jolene Zheng ${ }^{2}$ \\ ${ }^{1}$ School of Animal Sciences, College of Agriculture, Louisiana State University, Baton Rouge, LA, 70808, USA \\ 2Pennington Biomedical Research Center, Louisiana State University, Baton Rouge, LA, 70808, USA \\ ${ }^{3}$ Department of Nutritional Sciences, Texas Tech University, Lubbock, TX, 79409, USA \\ ${ }^{4}$ School of Nutrition and Food Science, College of Agriculture, Louisiana State University, Baton Rouge, LA, 70803, USA \\ 5 University of California, University of California, Davis, CA, 95616, USA \\ ${ }^{6}$ Ingredion Incorporated, Bridgewater, NJ, 08807, USA
}

V1 First published: 01 Jun 2015, 4:139

https://doi.org/10.12688/f1000research.6451.1

Latest published: 01 Jun 2015, 4:139

https://doi.org/10.12688/f1000research.6451.1

\section{Abstract}

The rising prevalence of obesity and the vulnerability of the pediatric age group have highlighted the critical need for a careful consideration of effective, safe, remedial and preventive dietary interventions. Amylose starch (RS2) from high-amylose maize (HAM) ferments in the gut and affects body weight. One hundred and ten children, of 7-8 $(n=91)$ or $13-14(n=19)$ years of age scored the sensory qualities of a yogurt supplemented with either HAM-RS2 or an amylopectin starch. The amylopectin starch yogurt was preferred to the HAM-RS2-enriched yogurt by $7-8$ year old panelists $(P<0.0001)$. Appearance, taste, and sandiness scores given by 13- to 14-year-old panelists were more favorable for the amylopectin starch yogurt than for HAM-RS2-enriched yogurt $(P<0.05)$. HAM-RS2 supplementation resulted in acceptable ( $\geq 6$ on a 1-9 scale) sensory and hedonic ratings of the yogurt in $74 \%$ of subjects. Four children consumed a HAM-RS2enriched yogurt for four weeks to test its fermentability in a clinical trial. Three adolescents, but not the single pre-pubertal child, had reduced stool $\mathrm{pH}(P=0.1)$ and increased stool short-chain fatty acids (SCFAs) $(P<0.05)$ including increased fecal acetate $(P=0.02)$, and butyrate $(P=0.089)$ from resistant starch (RS) fermentation and isobutyrate $(P=0.01)$ from protein fermentation post-treatment suggesting a favorable change to the gut microbiota. HAM-RS2 was not modified by pasteurization of the yogurt, and may be a palatable way to increase fiber intake and stimulate colonic fermentation in adolescents. Future studies are planned to determine the concentration of HAM-RS2 that offers the optimal safe and effective

\section{Open Peer Review}

Approval Status

1

2

version 1

01 Jun 2015

$\checkmark$

$\checkmark$

1. Patrick O'Neil, Medical University of South

Carolina, Charleston, USA

2. Joanne Lupton, Texas A\&M University,

College Station, USA

Any reports and responses or comments on the article can be found at the end of the article. 
strategy to prevent excessive fat gain in children.

Keywords

fatty acids, fiber, home nutrition support

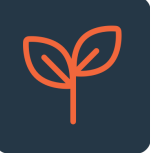

This article is included in the Agriculture, Food

and Nutrition gateway.

Corresponding authors: Frank Greenway (frank.greenway@pbrc.edu), Jolene Zheng (Jolene.Zheng@pbrc.edu)

Competing interests: C. Pelkman is an employee of Ingredion Incorporated. M. Keenan and R. Martin received grant support from Ingredion Incorporated. No competing interests were disclosed for other authors.

Grant information: This project was funded in part by Louisiana State University Agricultural Center (LAB 93724) and the Pennington Biomedical Research Center. This work was partially supported by a NORC Center Grant (\# 2P30DK072476) entitled "Nutritional Programming: Environmental and Molecular Interactions" sponsored by NIDDK. This work was supported in part by P50AT002776 from the National Center for Complementary and Alternative Medicine (NCCAM) and the Office of Dietary Supplements (ODS) which funds the Botanical Research Center of Pennington Biomedical Research Center and the Department of Plant Biology and Pathology in the School of Environmental and Biological Sciences (SEBS) of Rutgers University. This work was supported in part by 1 U54 GM104940 from the National Institute of General Medical Sciences of the National Institutes of Health which funds the Louisiana Clinical and Translational Science Center.

Copyright: @ 2015 Aryana $\mathrm{K}$ et al. This is an open access article distributed under the terms of the Creative Commons Attribution License , which permits unrestricted use, distribution, and reproduction in any medium, provided the original work is properly cited. Data associated with the article are available under the terms of the Creative Commons Zero "No rights reserved" data waiver (CC0 1.0 Public domain dedication).

How to cite this article: Aryana K, Greenway F, Dhurandhar $\mathrm{N}$ et al. A resistant-starch enriched yogurt: fermentability, sensory characteristics, and a pilot study in children [version 1; peer review: 2 approved] F1000Research 2015, 4:139

https://doi.org/10.12688/f1000research.6451.1

First published: 01 Jun 2015, 4:139 https://doi.org/10.12688/f1000research.6451.1 


\section{Clinical relevancy statement}

Resistant starch (RS) is a type of dietary fiber that people cannot digest, diluting caloric density, but is fermented by bacteria in the intestines into short chain fatty acids that have been shown in other studies to stimulate the production of appetite reducing hormones (see the text). We incorporated resistant starch into a yogurt that was generally accepted by children, increased their dietary fiber consumption and increased colonic fermentation in adolescents. This pilot data suggest the need for a study testing the ability of this yogurt to treat childhood obesity, a vulnerable group where nonfood solutions are limited.

\section{Introduction}

The rapidly-growing prevalence of obesity in adults and children requires urgent remedial measures to avert individual and societal health care crises ${ }^{1}$. Few adult treatment strategies exist ${ }^{2}$, treating children is more challenging, yet childhood obesity is a growing health concern ${ }^{3}$. Pediatric vulnerability severely limits the use of pharmacological or surgical interventions. Even dietary treatment with energy and nutrient restriction for weight reduction may be detrimental to growth. Dietary resistant starch (RS) supplementation in food may offer a therapeutic opportunity to attenuate excessive fat gain in infants and children by reducing the caloric density while improving dietary quality ${ }^{1,2}$.

RS are dietary carbohydrates that resist cooking processes and enzymatic digestion in the small intestine, are fermented by colonic microbiota and modify the gut flora ${ }^{4,5}$. The amount of RS in the human diet has progressively decreased with modern milling and food preparation methods. RS intake in medieval Europe was $50-100 \mathrm{~g} / \mathrm{day}^{6}$, it is estimated at $30-40 \mathrm{~g} / \mathrm{day}^{7}$ in developing countries, and has dropped to $3-8 \mathrm{~g} /$ day in developed countries ${ }^{7-9}$. It is unlikely that modern human society will return to a diet of coarsely ground grains and legumes high in RS. However, RS is now available as an ingredient that can be incorporated into breads, cereal products and baked goods that are acceptable to the US population.

Microbiota-derived enzymes are needed to digest complex plant polysaccharides ${ }^{10}$ and RS-enriched diets increase butyrate-producing Clostridia in rodent feces ${ }^{11}$. A natural, granular, type 2 RS from high-amylose maize (HAM-RS2) decreases plasma cholesterol and triglycerides, increases satiety, increases insulin sensitivity ${ }^{12-22}$, and is anti-adipogenic in adult populations ${ }^{23-30}$. HAM-RS2 fermentation in the colon of rodents produces short chain fatty acids (SCFAs) such as acetate, propionate and butyrate that are absorbed through colonocytes, and change colonic microbiota composition ${ }^{25,31,32}$. Butyrate treatment increases gene expression of peptide tyrosine tyrosine (PYY) and proglucagon in ileal, primary colon and cecal epithelial cells of rats; elevates plasma Glucagon-like peptide-1 and -2 (GLP-1, GLP-2), and raises gene expression and protein produc-

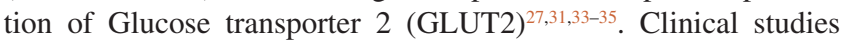
show that SCFAs increase in response to consumption of HAMRS2 or RS from potatoes ${ }^{36-38}$, that the microbiota of rodents were modified $^{39}$, and that butyrate was increased in rodents after dietary introduction of human feces ${ }^{40}$. Since yogurt can deliver dietary fibers to treat constipation in children ${ }^{41}$, the aim of the current work is to develop a palatable yogurt delivery vehicle for HAM-RS2 that will withstand pasteurization and demonstrate an increase in fecal $\mathrm{pH}$ and SCFAs in children and adolescents.

\section{Methods}

\section{The RS yogurt manufacture}

Yogurt mixes were made by incorporating the starches individually into skim milk. The yogurt mixes were pasteurized at $65.5^{\circ} \mathrm{C}$ for $30 \mathrm{~min}$, cooled to $40^{\circ} \mathrm{C}$, inoculated with freshly thawed Streptococcus thermophilus (ST-M5) $(3.1 \mathrm{E}+10 \mathrm{cfu} / \mathrm{g}, 1 \mathrm{ml})$ and Lactobacillus bulgaricus (LB-12) (3E+10 cfu/g, 1ml) (Chr. Hansen Inc., Milwaukee, WI) per $3.785 \mathrm{~L}$ ( 1 gallon), then incubated at $40^{\circ} \mathrm{C}$ until they reached a $\mathrm{pH} 4.5$, and held at $4{ }^{\circ} \mathrm{C}$ overnight. Blueberry puree $(20 \% \mathrm{w} / \mathrm{w})$ was incorporated into the yogurt the following day and amylopectin starch $\left(15 \mathrm{~g}\right.$, control, AMIOCA ${ }^{\circledR}$ corn starch, Ingredion Incorporated, Bridgewater, NJ) or HAM-RS2 (15g, HI-MAIZE ${ }^{\circledR} 260$ resistant starch, Ingredion Incorporated, Bridgewater, NJ) per $237 \mathrm{ml}$ serving was added to the yogurt (Creamery, College of Agriculture, LSU). A high performance liquid chromatography (HPLC) peak was detected in our HAM-RS2 sample and RS accounted for $38.2 \%$ of the sample.

\section{In vitro testing}

HAM-RS2 30g/237ml yogurt was used for in vitro testing. Six samples were prepared, coded, and tested blindly with half subjected to pasteurization. A modified Englyst method was used to quantify glucose release ${ }^{4}$. Intact granular structure of the starch was evaluated using birefringence light microscopy.

\section{Sensory study}

The Institutional Review Board (IRB) granted an exemption \#HE13-1 (January 16, 2013) from continued oversight for the sensory study conducted in two groups of children evaluating the two yogurts. Ratings of satisfaction with the appearance, color, aroma, taste, thickness, sandiness, and palatability of each type of yogurt were scored by 110 children without communication. Ninety-one children were 7-8 years old (younger) and 19 were 13-14 years old (elder). The younger children were more willing to volunteer for the sensory study than the elder.

Subjects with no dairy or starch-related allergies were recruited from The Louisiana State University Laboratory School and parental consent to participate was obtained along with the children's assent. Participants were given yogurt samples in $85 \mathrm{~g}$ cups with a snap-on lid. Cups were coded with a random three-digit number. Disposable plastic spoons and napkins were provided to prevent contamination between samples. Prior to the sensory evaluation, the children were provided with a "warm-up" yogurt sample to avoid the "first sample effect" due to possible previous consumption of other food items, and a cup of drinking water was provided to rinse their palate between samplings. Two evaluation forms were used, one with a face scale for the younger panelists and the other with a preference rating form for the older panelists, and clearly explained to each age group. The younger panelists indicated their yogurt preference by circling "smiling face (-) as yes", scored as 3, "neutral face (-) as neither like nor dislike", scored as 2, or "sad face (:) as no", scored as 1 . The elder panelists evaluated the yogurt on a 1-9 scale (1-dislike extremely, 2-dislike very much, 3-dislike moderately, 4-dislike slightly, 5-neither like nor dislike, 6-like slightly, 7-like moderately, 8-like very much, 9-like extremely) for appearance, color, aroma, taste, thickness, and sandiness. The elder panelists evaluated the yogurt thickness by checking 1-too thin, 2-just about right, or 3-too thick; and the sandiness as 1-not grainy, 2-just about 
right, or 3-too grainy. Elder panelists answered the question "Is this product acceptable?" with 2-“yes" or 1-“no" answer.

\section{Clinical study}

The four-week pilot clinical trial was approved by the PBRC Institutional Review Board (IRB28012) and registered (http://clinicaltrials.gov/, NCT01338571) to determine the effects of consuming HAM-RS2-enriched yogurt on fecal $\mathrm{pH}$ and fecal SCFAs, pre- and post-consumption, in a healthy child and three healthy adolescents. The subjects (a 6-year-old female, two 10-year-old African-American females, and a 14-year-old Caucasian male) were recruited through the PBRC recruiting department. Parents signed a consent form and subjects signed an assent form. Subjects with gastrointestinal disease, on medications with the potential to alter the intestinal bacterial microbiota such as antibiotics and subjects with allergies to corn were specifically excluded.

Subjects were weighed in the morning on an electronic scale in light street clothing without shoes or outer clothing and with pockets emptied. The electronic scale (Model 450, GSE Inc., Livonia, MI, USA) was calibrated daily using standardized weights and quarterly by an external service. Parents were given stool-collecting kits and instructed to collect a stool specimen from their child for 3 consecutive days at baseline and after 4 weeks of yogurt consumption. They were provided with ice packs, coolers and were instructed to return stool samples in the coolers to the research site on the day they were collected so they could be stored at $-70^{\circ} \mathrm{C}$ until analysis.

Children were given HAM-RS2 $10 \mathrm{~g}$ plus $1 \mathrm{~g}$ per year of age daily ${ }^{42}$ which was 16,20 , or $24 \mathrm{~g}$ for the four subjects. A fresh supply of yogurt was given to the parents weekly and the daily yogurt was divided into servings at breakfast and dinner.

Measurements of fecal SCFAs and $\mathrm{pH}$ were previously published elsewhere ${ }^{18}$. Briefly, the frozen fecal specimens were thawed, homogenized and further diluted to wet sample in distilled water $(0.5 \mathrm{~g} / 5 \mathrm{ml})$. The $\mathrm{pH}$ was measured using a combination electrode. Samples were then acidified with metaphosphoric acid $(250 \mathrm{~g} / \mathrm{L}$, $1 \mathrm{ml})$ containing ethyl-butyric acid $(2 \mathrm{~g} / \mathrm{L})$ as an internal standard. The mixture was vortexed, and centrifuged at $4{ }^{\circ} \mathrm{C}$ for 10 minutes at $8,000 \mathrm{rpm}$ to remove solids in the homogenized samples and syringefiltered (33mm, Millipore, Billerica, MA). The filtrate was put into a gas chromatograph (GC) auto-sampler vial and capped. SCFAs in the effluent were analyzed using gas-liquid chromatography. The $\mathrm{GC}$ conditions $\left(115^{\circ} \mathrm{C}\right.$ for $\left.0.1 \mathrm{~min}\right)$ were increased to $150^{\circ} \mathrm{C}$ for 0.1 min in increments of $10^{\circ} \mathrm{C}$, then to $170^{\circ} \mathrm{C}$ for $2 \mathrm{~min}$ at increments of $11^{\circ} \mathrm{C}$. The injector temperature was $250^{\circ} \mathrm{C}$. Helium was the carrier gas with a flow rate of $60 \mathrm{ml} / \mathrm{min}$ and splitless injection was $60 \mathrm{ml} / \mathrm{min}$. Single SCFAs were determined by retention time based on standards and the relative concentrations calculated based on the ratio of the peak areas of the sample to the internal standard.

\section{Statistical analysis}

The RS content differences of yogurt samples prepared with or without pasteurization were determined using the Student $t$-test (SAS 9.3, SAS Institute Inc., Cary, NC). The sensory data obtained from children were analyzed with a Randomized Block Design using panelists as blocks (GLM, SAS 9.1), and the paired $t$-test for HAM-RS2 score minus amylopectin score was performed.
Differences between the types of yogurt were determined by differences of least squares mean \pm SEM. The clinical data analysis of feeding yogurt to the four subjects was performed with the Student $t$-test (weight) and paired $t$-test (change in weight) (SAS 9.1). Alpha was set at 0.05 .

\section{Ethics}

All procedures followed were in accordance with the ethical standards of the responsible committee on human experimentation (institutional and national) and with the Helsinki Declaration of 1975, as revised in 2000.

\section{Results}

\section{Resistant starch in yogurt}

The glucose release was detected by a modified Englyst method. A light microscope (200x, Leitz Wetzlar, Ortholux II, Ernst Leitz $\mathrm{GmbH}$, Wetzlar, Germany) revealed morphologies of the starch granules in the yogurts as having an equal presence of birefringence indicating an intact granular structure (Figure 1). The RS content of the six yogurt samples varied minimally (from $45 \%$ to $51 \%$ on a dry weight basis with values of $51 \%, 45 \%$, or $48 \%$ for the unpasteurized samples, and $45 \%, 45 \%$, or $46 \%$ for the pasteurized samples $(P>0.05)$.
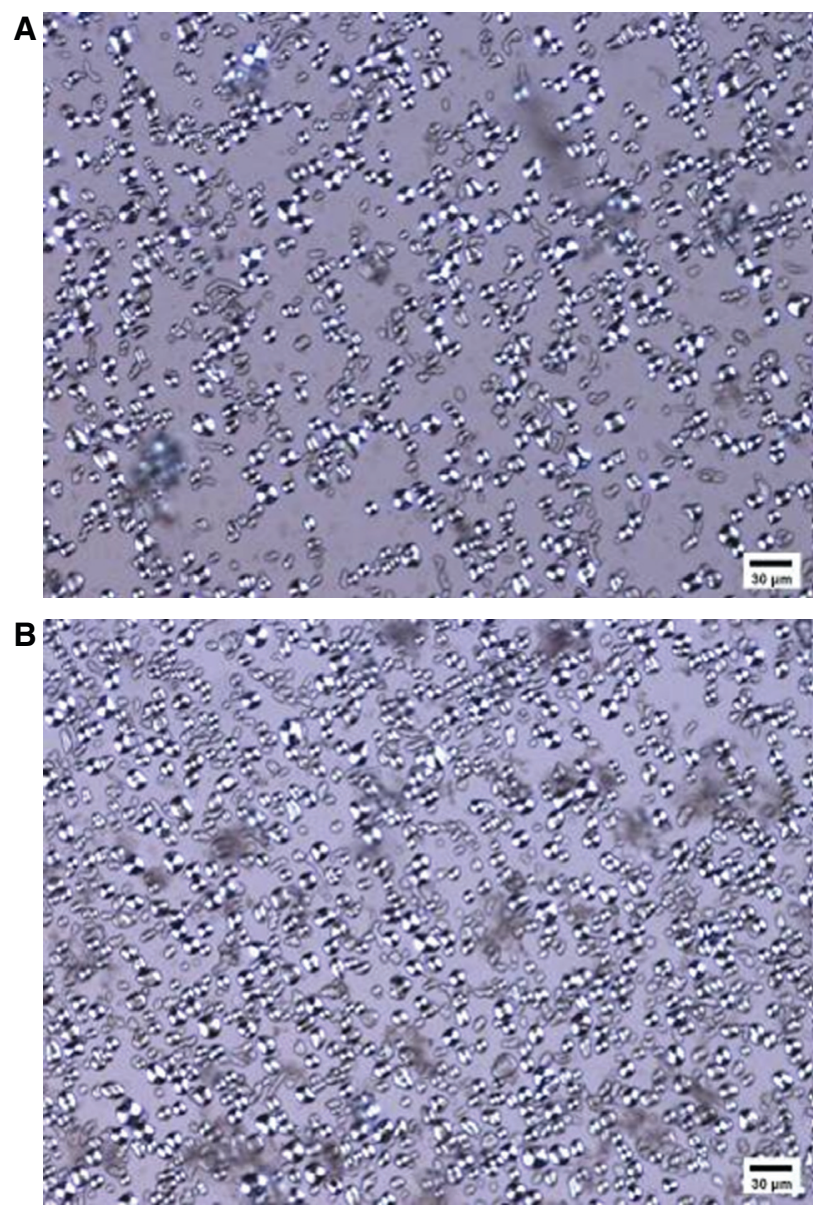

Figure 1. HAM-RS2-enriched yogurt observed using polarized light microscopy (200x). Bar=30 $\mu \mathrm{m}$. 
Sensory results for HAM-RS2 versus amylopectin starch Group 1: Ninety-one 7- and 8-year-old panelists. The average scores were 1.538 for the HAM-RS2-yogurt and 2.143 for the amylopectin starch yogurt. The difference was $-0.604 \pm 0.1(\mathrm{t}=6.05$, $P<0.0001)$ which indicated that the amylopectin starch yogurt was preferred over the HAM-RS2-yogurt.

Group 2: Nineteen 13- and 14-year-old panelists. No score differences were detected in color $(6.95 \pm 0.36$ vs. $7.05 \pm 0.28)$ and aroma (7.84 \pm 0.24 vs. $7.47 \pm 0.32$ ) for the amylopectin starch compared to the HAM-RS2-yogurt, respectively (Table 1, P>0.05). However, appearance $(6.84 \pm 0.34$ vs. $4.58 \pm 0.38)$, taste $(6.95 \pm 0.32$ vs. $4.84 \pm 0.49)$, thickness $(6.74 \pm 0.48$ vs. $4.47 \pm 0.37)$, and sandiness $(6.26 \pm 0.37$ vs. $3.05 \pm 0.36)$ scores for the amylopectin starch yogurt were higher than for the HAM-RS2-yogurt $(P<0.005)$.

On a 1-3 scale (1-too thin, 2-just about right, or 3-too thick), the amylopectin starch yogurt $(2.26 \pm 0.13)$ was judged slightly thicker than just about right while the HAM-RS2-yogurt (1.16 \pm 0.09$)$ was judged as too thin $(P<0.0001$, Table 2$)$.

Using a 1-3 scale (1-not grainy, 2-just about right, and 3-too grainy), the HAM-RS2-yogurt $(2.84 \pm 0.12)$ was judged as too grainy but was acceptable to $74 \%$ of the children of 13-14 years of age, while the amylopectin starch yogurt $(1.95 \pm 0.12)$ was judged as just about right (Table 2, $P<0.0001$ ).

The amylopectin starch yogurt was always judged as acceptable (Table 2) and its acceptability on a 1-2 scale (1-not acceptable or 2acceptable) was significantly higher than for the HAM-RS2-yogurt
$(P<0.05)$. The sensory study indicated that children preferred the amylopectin starch yogurt more than the HAM-RS2 added yogurt.

Dataset 1 . Sensory raw data from study participants

http://dx.doi.org/10.5256/f1000research.6451.d47918

Participants were asked to rate amylopectin starch- and HAMRS2-containing yogurts for preference ( $7-8$ years old; $1-3$ scale, 1 being dislike, 3 being like) or appearance, color, aroma, taste, thickness, and sandiness (13-14 year olds; 1-9 scale, 1 being dislike extremely, 9 being like extremely $)^{45}$.

\section{Clinical study}

All adolescent participants finished the HAM-RS2-yogurt and returned the empty containers during the weekly clinic visits with no complaints regarding taste or compliance issues related to consumption of the yogurt.

One 10-year-old had a BMI of $19.8 \mathrm{~kg} / \mathrm{m}^{2}$ and the other had a BMI of $27.1 \mathrm{~kg} / \mathrm{m}^{2}$. The 14-year-old had a BMI of $31.5 \mathrm{~kg} / \mathrm{m}^{2}$. All were otherwise healthy. The pre-pubertal child gained $1.9 \mathrm{~kg}(39.5$ to $41.4 \mathrm{~kg})$. One of the adolescent females gained $3.2 \mathrm{~kg}$ (49.6 to $52.8 \mathrm{~kg}$ ), the other one gained $0.4 \mathrm{~kg}(69.5$ to $69.9 \mathrm{~kg})$ and the adolescent male gained $1.7 \mathrm{~kg}(89.9$ to $91.6 \mathrm{~kg})(P>0.05)$.

SCFAs $(\mu \mathrm{g} / \mathrm{g}$ wet stool weight) from carbohydrate fermentation were increased in the adolescent participants; in ascending order, butyrate $(23 \%, 2,410 \pm 691$ to $3,144 \pm 1,509 \mu \mathrm{g}, P=0.09)$, acetate ( $26 \%, 5,078 \pm 492$ to $6,870 \pm 515 \mu \mathrm{g}, P=0.02)$, but not propionate

Table 1. Comparison of the appearance, color, aroma, taste, thickness, and sandiness score (on a 1 to 9 scale in which 1 was the least desirable ranking and 9 was the most desirable ranking) of the HAM-RS2 (treatment) versus the amylopectin starch (control) yogurt when evaluated by 13- and 14-year-old children.

\begin{tabular}{|l|l|l|l|l|l|l|}
\hline $\begin{array}{l}\text { Type of starch } \\
\text { present in yogurt }\end{array}$ & Appearance & Color & Aroma & Taste & Thickness & Sandiness \\
\hline Amylopectin starch & $6.84^{\mathrm{a}} \pm 0.34$ & $6.95^{\mathrm{a}} \pm 0.36$ & $7.84^{\mathrm{a}} \pm 0.24$ & $6.95^{\mathrm{a}} \pm 0.32$ & $6.74^{\mathrm{a}} \pm 0.48$ & $6.26^{\mathrm{a}} \pm 0.37$ \\
\hline HAM-RS2 & $4.58^{\mathrm{b}} \pm 0.38$ & $7.05^{\mathrm{a}} \pm 0.28$ & $7.47^{\mathrm{a}} \pm 0.32$ & $4.84^{\mathrm{b}} \pm 0.49$ & $4.47^{\mathrm{b}} \pm 0.37$ & $3.05^{\mathrm{b}} \pm 0.36$ \\
\hline
\end{tabular}

abMeans without a common superscript are significantly $(P<0.05)$ different from each other.

Table 2. Comparison of the thickness score $(1=$ too thin, $2=$ just about right, or $3=$ too thick), the sandiness score ( 1 = not grainy, 2 = just about right, or $3=$ too grainy), and the acceptability score $(1=$ no (not acceptable) or 2 = yes (acceptable)) of the HAM-RS2 (treatment) versus the amylopectin starch (control) yogurt when evaluated by $13-$ to 14-year-old children.

\begin{tabular}{|c|c|c|c|}
\hline $\begin{array}{l}\text { Type of starch } \\
\text { present in yogurt }\end{array}$ & $\begin{array}{l}\text { Thickness Score } \\
1=\text { too thin } \\
2 \text { = just about right } \\
3=\text { too thick }\end{array}$ & $\begin{array}{l}\text { Sandiness Score } \\
1 \text { = not grainy } \\
2 \text { = just about right } \\
3 \text { = too grainy }\end{array}$ & $\begin{array}{l}\text { Acceptability Score } \\
1 \text { = no (not acceptable) } \\
2 \text { = yes (acceptable) }\end{array}$ \\
\hline Amylopectin starch & $2.26^{a} \pm 0.13$ & $1.95^{b} \pm 0.12$ & $2.00^{a}$ \\
\hline HAM-RS2 & $1.16^{b} \pm 0.09$ & $2.84^{a} \pm 0.12$ & $1.74^{b}$ \\
\hline
\end{tabular}

${ }^{a b}$ Means without a common superscript are significantly $(P<0.05)$ different from each other. 
$(2,387 \pm 645$ to $1,889 \pm 120 \mu \mathrm{g}, P>0.05)$. The isobutyrate from protein fermentation increased $(39 \%, 285 \pm 31$ to $471 \pm 58 \mu \mathrm{g}, P=0.01)$ (Figure 2). The stool $\mathrm{pH}$ of the adolescents was mildly reduced at the end of the fourth week with a trend toward a lower $\mathrm{pH}(2.8 \%$, from 7.2 \pm 0.4 to $7.0 \pm 0.35, P=0.1$, Figure 3).

The pre-pubertal participant responded to HAM-RS2-enrichedyogurt differently than the three adolescent children with an increase in stool $\mathrm{pH}$ (from 6.89 to 7.62 ). The stool SCFAs were decreased; in ascending order, isobutyrate (35\%, from 526 to $186 \mu \mathrm{g}$ ), butyrate ( $39 \%$, from 4,028 to $1,571 \mu \mathrm{g}$ ), acetate ( $52 \%$, from $8,328$ to $4,336 \mu \mathrm{g})$, and propionate $(65 \%$, from 2,870 to $1,877 \mu \mathrm{g})$ over the 4-week study.

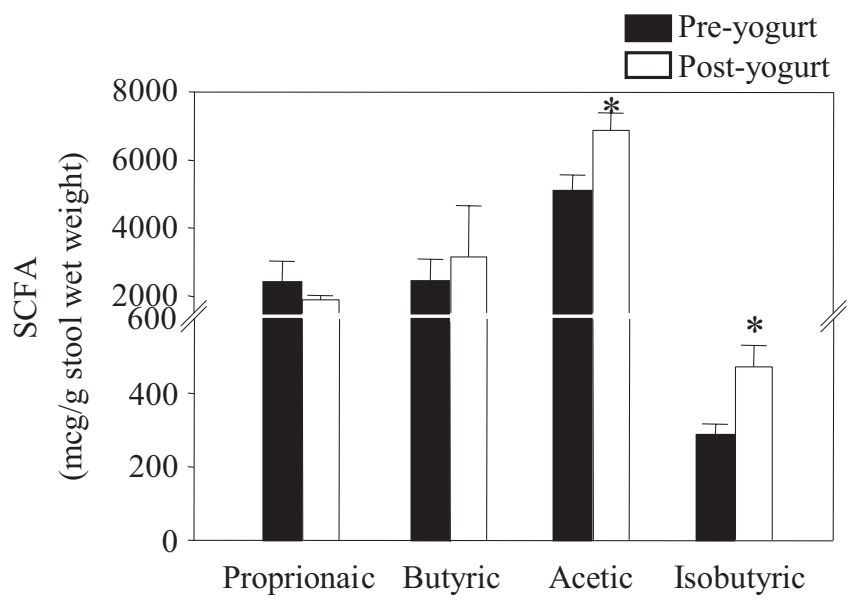

Figure 2. Stool SCFAs increased $(P<0.05)$ in adolescents post-yogurt treatment. The pre-pubertal child was not included.

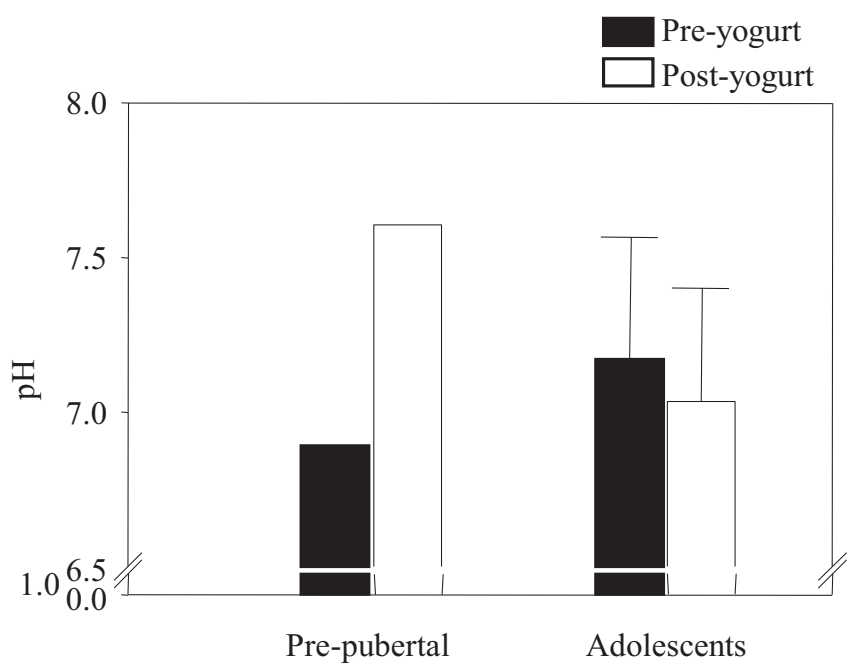

Figure 3. Stool $\mathrm{pH}$ was reduced $(P=0.1)$ in adolescents postyogurt treatment. The $\mathrm{pH}$ was increased in the pre-pubertal child.

\section{Dataset 2. Raw data for clinical study}

http://dx.doi.org/10.5256/f1000research.6451.d48004

Four participants (a 6-year-old female, two 10-year-old AfricanAmerican females, and a 14-year-old Caucasian male) were weighed and their weights recorded. Parents were given stoolcollecting kits and instructed to collect a stool specimen from their child for 3 consecutive days at baseline and after 4 weeks of yogurt consumption. They were provided with ice packs, coolers and were instructed to return stool samples in the coolers to the research site on the day they were collected so they could be stored at $-70^{\circ} \mathrm{C}$ until analysis. Children were given HAM-RS2 $10 \mathrm{~g}$ plus $1 \mathrm{~g}$ per year of age daily which was 16,20 , or $24 \mathrm{~g}$ for the four subjects. SCFA content of samples was analysed by GL-chromatography and determined by retention time based on standards and the relative concentrations calculated based on the ratio of the peak areas of the sample to the internal standard ${ }^{46}$

\section{Discussion}

The prevalence of childhood obesity has increased 2- to 3-fold in just the last 25 years globally (see review 2). Childhood obesity is associated with co-morbidities similar to adults including hypertension, dysglycemia, dyslipidemia, inflammation and endothelial dysfunction $^{2}$. Supplementing other treatment approaches with behavioral interventions may increase long term participation and is felt to be more important in the pediatric population than for adults ${ }^{2}$, but meta-analyses show prevention or treatment strategies to be ineffective. Currently, no truly effective pharmacological options are available for weight management, and surgery is restricted to a highly selected subgroup of very obese adolescent individuals. Medication and surgery have safety concerns in growing children and their efficacy is uncertain in the pediatric age group ${ }^{43}$. Novel treatments for childhood obesity offering safety, efficacy and acceptability are urgently needed ${ }^{44}$. Desirable attributes of an intervention for pediatric obesity include a preventive measure that attenuates excess fat accumulation while allowing for normal growth. RS is a natural food ingredient with a low risk profile that attenuates body fat accretion in experimental animal models, and is an excellent candidate to effectively combat childhood obesity. This feasibility study suggests that HAM-RS2-enriched foods likely alter microbiota composition, and this is supported by the increase in fecal SCFA content and lower $\mathrm{pH}$. Yogurt was a generally acceptable vehicle for providing HAM-RS2. The yogurt cultures fermented lactose (milk sugar) and the RS granules in the final yogurt product were not damaged.

Enriching the diet with RS which has been refined out of the US diet will improve dietary quality and may help to ease the severity of pediatric obesity. Although the amylopectin starch yogurt was preferred, our studies confirmed the general acceptability of incorporating HAM-RS2 into yogurt through taste and sensory testing in 91 7- to 8-year-olds and 19 13- to 14-year-old volunteers. The four subjects in our pilot study that consumed the HAM-RS2enriched yogurt twice a day for weeks established the feasibility of feeding the HAM-RS2-enriched yogurt to children. We demonstrated a trend toward a reduction of $\mathrm{pH}$ and documented a significant increase in the SCFA content of the stools of the adolescent 
children. This agrees with previous studies that have found that adding HAM-RS2 to rodent diets reduced abdominal fat in association with increased fermentation ${ }^{20,21,37,44}$. Supplementing the diet with RS will need to be acceptable and palatable or children are likely to reject it in favor of low-fiber alternatives. Overall, the HAMRS2-yogurt in the taste testing was acceptable to $74 \%$ of the children in the 13- to 14-year-old group, but $24 \%$ less acceptable in younger children. The knowledge that RS is healthy may increase the adoption of RS fortified foods, such as yogurt.

People eat for volume and consume fewer calories when food has a lower caloric density ${ }^{38}$. RS and other dietary fibers reduce the caloric density of food ${ }^{12,13,44}$. RS is present in many different sources, which offers the opportunity to choose the RS with the greatest success in reducing or controlling body weight ${ }^{17}$. We have previously shown that the HAM-RS2 supplementation produces a $30 \%$ reduction in intestinal fat deposition in wild type C. elegans ${ }^{28}$ and in rodents the same also reduced body fat ${ }^{25,44}$. Longer-term controlled studies are needed to determine if the reduced adiposity seen in animal models will occur in human populations. In a human pilot study, a HAMRS2 (15g/day) supplemented diet enhanced insulin sensitivity by $56.5 \%$ in men over two to three months, which suggests that lower amounts of HAM-RS2 may also be efficacious. Beneficial changes in adiposity may occur over longer treatment periods ${ }^{12,13,21,22}$, and lower amounts of RS may further improve palatability - an important factor for long-term consumption.

Children maintain weight loss better than adults ${ }^{11}$. Although it is not clear why the pre-pubertal child in this study did not respond in the same way as the adolescents, it could represent differences in her intestinal microbiota or her pre-treatment diet which was not controlled nor queried. Further research will be necessary to explore the differential role of diet and the intestinal microbiota on the fermentation of RS before puberty. Weight gain in all of the children during the 4-week study may reflect the fact that they were growing.

\section{Conclusion}

The current study showed the acceptability and feasibility of using yogurt to deliver RS to adolescents which caused a change in SCFA and probably changed the gut microbiota. These preliminary data suggest the need to evaluate differences that may exist in the microbiota before and after puberty to determine whether the non-response of the pre-pubertal child represented an outlier or a real effect in pre-pubertal children. These preliminary results will need confirmation in a controlled trial so that the effects of growth can be taken into account in evaluating weight changes in longer-term studies using yogurt as a vehicle to deliver the functional food component HAM-RS2 in a range of doses into everyday foods that consumers enjoy. Our data encourage controlled studies in children and adolescents testing insulin sensitivity, effects on body weight, and potential differences between pre-pubertal and adolescent children in their microbiota response to RS. Hopefully, increased consumption of reduced-calorie foods in combination with increased physical activity ${ }^{12}$ will reduce weight gain, help to maintain a healthier weight, and lead to future improvements in public health for adults and adolescents alike.
Data availability

F1000Research: Dataset 1 . Sensory raw data from study participants, 10.5256/f1000research.6451.d47918 ${ }^{45}$

F1000Research: Dataset 2. Raw data for clinical study, 10.5256/ f1000research.6451.d48004 ${ }^{46}$

\section{Consent}

Informed consent was obtained from all patients being included in the study.

\section{Author contributions}

Each individual has contributed to this manuscript as a qualified author and meets ALL of the requirements following the American Medical Association (AMA) manual guidelines. KJ Aryana, C Pelkman, and D Olson contributed to the conception and design of sensory study, acquisition of data, analysis and interpretation of the data, and drafting or editing the manuscript. $\mathrm{R}$ Tulley performed stool test and the SCFA analysis. FL Greenway and NV Dhurandhar designed the clinical study, contributed to its conception, acquisition of data, analysis and interpretation of the data, and drafting the manuscript. JW Finley, MJ Keenan, RJ Martin, and J Zheng contributed to designing of the sensory study, data analysis and interpretation, and drafting or editing the manuscript. All authors have approved the final version of the manuscript.

\section{Competing interests}

C. Pelkman is an employee of Ingredion Incorporated. M. Keenan and R. Martin received grant support from Ingredion Incorporated. No competing interests were disclosed for other authors.

\section{Grant information}

This project was funded in part by Louisiana State University Agricultural Center (LAB 93724) and the Pennington Biomedical Research Center. This work was partially supported by a NORC Center Grant (\# 2P30DK072476) entitled "Nutritional Programming: Environmental and Molecular Interactions" sponsored by NIDDK. This work was supported in part by P50AT002776 from the National Center for Complementary and Alternative Medicine (NCCAM) and the Office of Dietary Supplements (ODS) which funds the Botanical Research Center of Pennington Biomedical Research Center and the Department of Plant Biology and Pathology in the School of Environmental and Biological Sciences (SEBS) of Rutgers University. This work was supported in part by 1 U54 GM104940 from the National Institute of General Medical Sciences of the National Institutes of Health which funds the Louisiana Clinical and Translational Science Center.

\section{Acknowledgements}

This paper was approved for publication by the Director of Louisiana Agricultural Experiment Station as manuscript No. 2012237-7031. High-amylose maize (HI-MAIZE 260 resistant starch) and AMIOCA corn starch were donated by Ingredion Incorporated. (Bridgeport, NJ). The authors would like to thank Dr. Danuta Janik for her assistance on the light microscopy. 
1. Anderson JW, Patterson K: Snack foods: comparing nutrition values of excellent choices and "junk foods". J Am Coll Nutr. 2005; 24(3): 155-156. PubMed Abstract | Publisher Full Text

2. Ebbeling $\mathrm{CB}$, Pawlak DB, Ludwig DS: Childhood obesity: public-health crisis, common sense cure. Lancet. 2002; 360(9331): 473-482.

PubMed Abstract | Publisher Full Text

3. Durant N, Baskin ML, Thomas O, et al.: School-based obesity treatment and prevention programs: all in all, just another brick in the wall? Int $J$ Obes (Lond). 2008; 32(12): 1747-1751

PubMed Abstract | Publisher Full Text | Free Full Text

4. Englyst HN, Kingman SM, Cummings JH: Classification and measurement of nutritionally important starch fractions. Eur J Clin Nutr. 1992; 46(Suppl 2): S33-S50.

PubMed Abstract

5. Mahadevamma S, Shamala TR, Tharanathan RN: Resistant starch derived from processed legumes: in vitro and in vivo fermentation characteristics. Int $J$ Food Sci Nutr. 2004; 55(5): 399-405.

PubMed Abstract | Publisher Full Text

6. Birket A, Marie A: Dietary resistant starch interacts with non-starch polysaccharide and protein to influence colonic protein fermentation, with possible implication for colon cancer risk in humans. [Ph.D. thesis], Deakin University, Australia. 1997

Reference Source

7. Baghurst KI, Record SJ, Baghurst PA: Dietary fiber, non-starch polysaccharide and resistant starch intakes in Australia. In: Spiller G ed. CRC Handbook of dietary Fiber in Human Health. Boca Raton, Florida.: CRC Press LLC. 2001; 583-591.

Publisher Full Text

8. Dyssler PH: Estimation of resistant starch intake in Europe. In: van Amelsvoor JMH, ed. Wagneningen, The Netherlands.: EURESTA, N-G Asp.; 1994; 84-86.

9. Brighenti $\mathrm{F}$, Casiraghi MC, Baggio C: Resistant starch in the Italian diet. Br J Nutr. 1998; 80(4): 333-341. PubMled Abstract

10. Flint HJ, Bayer EA, Rincon MT, et al.: Polysaccharide utilization by gut bacteria: potential for new insights from genomic analysis. Nat Rev Microbiol. 2008; 6(2): 121-131.

PubMed Abstract | Publisher Full Text

11. Sharp R, Macfarlane GT: Chemostat enrichments of human feces with resistant starch are selective for adherent butyrate-producing clostridia at high dilution rates. Appl Environ Microbiol. 2000; 66(10): 4212-4221. PubMed Abstract | Publisher Full Text | Free Full Text

12. Robertson MD, Bickerton AS, Dennis AL, et al:: Insulin-sensitizing effects of dietary resistant starch and effects on skeletal muscle and adipose tissue metabolism. Am J Clin Nutr. 2005; 82(3): 559-567. PubMed Abstract

13. Robertson MD, Currie JM, Morgan LM, et al:: Prior short-term consumption of resistant starch enhances postprandial insulin sensitivity in healthy subjects. Diabetologia. 2003; 46(5): 659-665.

PubMed Abstract | Publisher Full Text

14. Brown IL: Applications and uses of resistant starch. J AOAC Int. 2004; 87(3): 727-732.

PubMed Abstract

15. Cassidy A, Bingham SA, Cummings JH: Starch intake and colorectal cancer risk: an international comparison. Br J Cancer. 1994; 69(5): 937-942. PubMed Abstract | Publisher Full Text | Free Full Text

16. de Deckere EA, Kloots WJ, van Amelsvoort JM: Resistant starch decreases serum total cholesterol and triacylglycerol concentrations in rats. J Nutr. 1993; 123(12): 2142-2151.

PubMed Abstract

17. Higgins JA: Resistant starch: metabolic effects and potential health benefits. J AOAC Int. 2004; 87(3): 761-768.

PubMed Abstract

18. Kendall CW, Esfahani A, Hoffman AJ, et al:: Effect of novel maize-based dietary fibers on postprandial glycemia and insulinemia. J Am Coll Nutr. 2008; 27(6): 711-718.

PubMed Abstract | Publisher Full Text

19. Anderson $\mathrm{GH}, \mathrm{Cho} \mathrm{CE}$, Akhavan T, et al:: Relation between estimates of cornstarch digestibility by the Englyst in vitro method and glycemic response, subjective appetite, and short-term food intake in young men. Am J Clin Nutr. 2010; 91(4): 932-939.

PubMed Abstract | Publisher Full Text

20. Willis $\mathrm{HJ}$, Eldridge $\mathrm{AL}$, Beiseigel J, et al.: Greater satiety response with resistant starch and corn bran in human subjects. Nutr Res. 2009; 29(2): 100-105. PubMed Abstract | Publisher Full Text

21. Johnston KL, Thomas EL, Bell JD, et al.: Resistant starch improves insulin sensitivity in metabolic syndrome. Diabet Med. 2010; 27(4): 391-397. PubMed Abstract | Publisher Full Text

22. Maki KC, Pelkman CL, Finocchiaro ET, et al:: Resistant starch from high-amylose maize increases insulin sensitivity in overweight and obese men. J Nutr. 2012;
142(4): 717-723.

PubMed Abstract | Publisher Full Text | Free Full Text

23. Bray GA, Greenway FL: Current and potential drugs for treatment of obesity Endocr Rev. 1999; 20(6): 805-875

PubMed Abstract | Publisher Full Text

24. Zhou J, Martin RJ, Tulley RT, et al.: Dietary resistant starch upregulates tota GLP-1 and PYY in a sustained day-long manner through fermentation in rodents. Am J Physiol Endocrinol Metab. 2008; 295(5): E1160-1166. PubMed Abstract | Publisher Full Text | Free Full Text

25. Keenan MJ, Zhou J, McCutcheon KL, et al: Effects of resistant starch, a non-digestible fermentable fiber, on reducing body fat. Obesity (Silver Spring). 2006; 14(9): 1523-1534.

PubMed Abstract | Publisher Full Tex

26. Greenway F, O'Neil CE, Stewart L, et al:: Fourteen weeks of treatment with Viscofiber ${ }^{\oplus}$ increased fasting levels of glucagon-like peptide-1 and peptide-YY. $J$ Med Food. 2007; 10(4): 720-724

PubMed Abstract | Publisher Full Text

27. Zhou J, Hegsted M, McCutcheon KL, et al.: Peptide YY and proglucagon mRNA expression patterns and regulation in the gut. Obesity (Silver Spring). 2006: 14(4): 683-689.

PubMled Abstract | Publisher Full Text

28. Zheng J, Enright F, Keenan M, et al.: Resistant starch, fermented resistant starch, and short-chain fatty acids reduce intestinal fat deposition in Caenorhabditis elegans. J Agric Food Chem. 2010; 58(8): 4744-4748. PubMed Abstract | Publisher Full Text

29. Venema K, van den Abbeele P: Experimental models of the gut microbiome. Best Pract Res Clin Gastroenterol. 2013; 27(1): 115-126. PubMed Abstract | Publisher Full Tex

30. den Besten G, van Eunen K, Groen AK, et al:: The role of short-chain fatty acids in the interplay between diet, gut microbiota, and host energy metabolism. $J$ Lipid Res. 2013; 54(9): 2325-2340.

PubMed Abstract | Publisher Full Text | Free Full Text

31. Mangian HF, Tappenden KA: Butyrate increases GLUT2 mRNA abundance by initiating transcription in Caco2-BBe cells. JPEN J Parenter Enteral Nutr. 2009; 33(6): 607-617; discussion 617.

PubMed Abstract | Publisher Full Text

32. Tappenden KA, McBurney MI: Systemic short-chain fatty acids rapidly alter gastrointestinal structure, function, and expression of early response genes. Dig Dis Sci. 1998; 43(7): 1526-1536. PubMed Abstract | Publisher Full Text

33. Zhou J, Keenan MJ, Fernandez-Kim SO, et al.: Dietary resistant starch improves selected brain and behavioral functions in adult and aged rodents. Mol Nutr Food Res. 2013; 57(11): 2071-2074. PubMed Abstract | Publisher Full Text | Free Full Text

34. Tachon S, Zhou J, Keenan M, et al:: The intestinal microbiota in aged mice is modulated by dietary resistant starch and correlated with improvements in host responses. FEMS Microbiol Ecol. 2013; 83(2): 299-309. PubMed Abstract | Publisher Full Text

35. Keenan MJ, Janes M, Robert $\mathrm{J}$, et al.: Resistant starch from high amylose maize (HAM-RS2) reduces body fat and increases gut bacteria in ovariectomized OVX) rats. Obesity (Silver Spring). 2013; 21(5): 981-984 PubMed Abstract | Publisher Full Text

36. Wang X, Brown IL, Khaled D, et al:: Manipulation of colonic bacteria and volatile fatty acid production by dietary high amylose maize (amylomaize) starch granules. J Appl Microbiol. 2002; 93(3): 390-397.

PubMed Abstract | Publisher Full Tex

37. Le Blay G, Michel C, Blottiere HM, et al.: Enhancement of butyrate production in the rat caecocolonic tract by long-term ingestion of resistant potato starch Br J Nutr. 1999; 82(5): 419-426. PubMed Abstract

38. Cheng HH, Lai MH: Fermentation of resistant rice starch produces propionate reducing serum and hepatic cholesterol in rats. $J$ Nutr. 2000; 130(8): 1991-1995.

PubMed Abstract

39. Tappenden KA, Deutsch AS: The physiological relevance of the intestinal microbiota--contributions to human health. J Am Coll Nutr. 2007; 26(6): 679S-683S.

PubMed Abstract | Publisher Full Text

40. Silvi S, Rumney CJ, Cresci A, et al:: Resistant starch modifies gut microflora and microbial metabolism in human flora-associated rats inoculated with faeces from Italian and UK donors. J Appl Microbiol. 1999; 86(3): 521-530. PubMed Abstract | Publisher Full Text

41. Kokke FT, Scholtens PA, Alles MS, et al:: A dietary fiber mixture versus lactulose in the treatment of childhood constipation: a double-blind randomized controlled trial. J Pediatr Gastroenterol Nutr. 2008; 47(5): 592-597. PubMed Abstract | Publisher Full Text

42. Tsiros MD, Sinn N, Coates AM, et al:: Treatment of adolescent overweight and obesity. Eur J Pediatr. 2008; 167(1): 9-16. PubMed Abstract | Publisher Full Text 
43. MacLean PS, Higgins JA, Jackman MR, et al:: Peripheral metabolic responses to prolonged weight reduction that promote rapid, efficient regain in obesity-prone rats. Am J Physiol Regul Integr Comp Physiol. 2006; 290(6): R1577-R1588. PubMed Abstract | Publisher Full Text

44. Belobrajdic DP, King RA, Christophersen CT, et al.: Dietary resistant starch dose dependently reduces adiposity in obesity-prone and obesity-resistant male rats. Nutr Metab (Lond). 2012; 9(1): 93.

PubMed Abstract | Publisher Full Text | Free Full Text
Aryana K, Greenway F, Dhurandhar N, et al.: Dataset 1 in: A resistant-starch enriched yogurt: fermentability, sensory characteristics, and a pilot study in children. F1000Research. 2015.

Data Source

46. Aryana K, Greenway F, Dhurandhar N, et al:: Dataset 2 in: A resistant-starch enriched yogurt: fermentability, sensory characteristics, and a pilot study in children. F1000Research. 2015

Data Source 


\section{Open Peer Review}

\section{Current Peer Review Status:}

\section{Version 1}

Reviewer Report 26 August 2015

https://doi.org/10.5256/f1000research.6923.r10019

(C) 2015 Lupton J. This is an open access peer review report distributed under the terms of the Creative Commons Attribution License, which permits unrestricted use, distribution, and reproduction in any medium, provided the original work is properly cited.

\section{Joanne Lupton}

Department of Nutrition and Food Science, Texas A\&M University, College Station, TX, USA

The authors are addressing an important issue -- the development of foods for children that will not impede their growth, but also not contribute to adiposity, that children will like to eat, and that will withstand pasteurization. In their case they have chosen to add a specific resistant starch (HAM-RS2)- to yogurt. There was a good rationale for them to select this resistant starch as previous studies done in rats, and some done in humans, have shown beneficial results. They performed a series of sensory tests comparing the yogurt with resistant starch to their control yogurt (containing amylopectin). Except for the color of the product all other sensory attributes were rated better for the control than the yogurt containing resistant starch. The statistical analyses appear to be acceptable except there was no stated allowance for multiple T tests. Despite this, it is clear that the children liked the control better than the one containing resistant starch. Instead of calling this product a "bust" the authors have chosen to call this a success as a certain percentage still liked the experimental product sufficiently to eat it. One wonders how the abstract would have read if the resistant starch containing product scores were reversed with the controls. One would imagine that they would have been delighted if not ecstatic.

The "clinical trial" in children was important to do, as it provided information as to the acceptability of the resistant starch over time. However, there were only 4 children in this trial and one, who was pre-pubescent (age 6), was different from the others (2) 10 y and (1) 14, and the results from that individual were also different from the other 3 . In one way this is really a preliminary test of the resistant starch, not a trial, as there was no control. All 4 children ate the resistant-starch yogurt, in amounts based, in part, on their ages. Again, the results of this trial were disappointing if weight gain was a primary outcome measure. All gained weight, and for some this was substantial. The resistant starch appeared to be fermented to SCFA, but the values for $\mathrm{pH}$ and SCFA were reported in a previous paper. If weight gain, or gain of muscle mass and not fat stores was an important endpoint and these children were still growing, the study would have benefitted by a control group of the amylopectin containing yogurt.

The title of the paper seems incomplete as it doesn't mention the aim of the pilot study. I've tried to come up with the purpose of the clinical trial, but the fact that I'm unsure what the goal was is 
impeding me. Is it testing the fermentability of the resistant starch product? If so, it should provide $\mathrm{pH}$ and SCFA data. Is it testing whether or not children will eat this product for a month, then it should say that. If it's about weight gain/loss then it needed a control.

In summary, I think this idea of accepting a paper and then asking experts in the field to comment is excellent, and I'm glad to be part of the process. These authors are experts in what they are doing, and they have found some important information about a natural, granular, type 2RS from high-amylose maize (HAM-RS2). Others working in this field can benefit from the fact that they presented their data in what could be characterized as a preliminary study. However, there are two points that bother me about the interpretation of their data. First, they put a very positive spin on the HAM-RS2 intervention, when by almost all accounts this was not a positive outcome. This really should be toned down. Second, the authors make statements about the benefits of fermentability that come across as "facts" when rather this is an open and unresolved issue. For example, when discussing HAM-RS2 they say "decreases plasma cholesterol and triglycerides, increases satiety, increases insulin sensitivity and is anti-adipogenic in adult populations." Although they show several citations that have shown this, they have not reviewed the entire literature, and they make the statement as if it is fact. This needs to be qualified. In a different place they say "People eat for volume and consume fewer calories when food has a lower caloric density." This is Barbara Rolls's hypothesis, but not everyone would agree with this statement. In fact, Rolls herself says it mostly applies to men, not women. So, please go back through your comments that are stated as FACTS and perhaps modify them.

Competing Interests: No competing interests were disclosed.

\section{I confirm that I have read this submission and believe that I have an appropriate level of expertise to confirm that it is of an acceptable scientific standard.}

Reviewer Report 30 June 2015

https://doi.org/10.5256/f1000research.6923.r8858

(C) 2015 O'Neil P. This is an open access peer review report distributed under the terms of the Creative Commons Attribution License, which permits unrestricted use, distribution, and reproduction in any medium, provided the original work is properly cited.

\section{Patrick O'Neil}

Department of Psychiatry and Behavioral Sciences, Medical University of South Carolina, Charleston, SC, USA

There is much current attention to the role of the gut, especially gut microbiota, in the regulation of body weight. At the same time the US and other countries face escalating rates of childhood and adolescent obesity, suggesting the importance of obesity prevention efforts, of which there have been few shown to have significant impacts. This study examines one innovative potential approach to preventing obesity targeting food components, specifically the incorporation of dietary resistant starch into a common food item, yogurt. The study focused on the acceptability of the sensory characteristics of yogurt enhanced with one such resistant starch, compared to 
yogurt enhanced with a control amylopectin starch, among pre-adolescent and adolescent subjects. A small pilot 4-week trial also looked at the effects of the resistant starch when consumed by 4 subjects.

The sensory evaluation study was well-designed with tight controls and a sizable N. Assessment of various sensory attributes was rather comprehensive among the adolescent sample, which unfortunately was substantially smaller than the sample of 7- to 8-year olds who could not be expected to make the finer sensory distinctions on which the adolescents were queried. The actual resistant starch content of the various yogurt samples was verified by analyses.

The sensory evaluation study showed that the subjects consistently preferred the control yogurt to that containing the resistant starch. The adolescents found the resistant starch yogurts to be inferior to the control yogurts on appearance, taste, thickness, sandiness and acceptability. About $25 \%$ of the adolescent subjects rated the resistant starch as unacceptable. Among the younger children, whose only ratings were a smiling face, neutral face or sad/frowning face, the resistant starch yogurt was more strongly disliked, with nearly two-thirds of subjects awarding it a frowning face. The discussion does not adequately address these results, which show consistently that the sensory characteristics of the resistant starch yogurt preparation are not well received by children and adolescents. The conclusion that "...our studies confirmed the general acceptability of incorporating HAM-RS2 into yogurt..." seems to fly in the face of these results.

The very small pilot clinical trial provided some support for the hypothesis that the resistant starch would produce changes in gut microbiota, findings worth following up with a larger study. It also showed that despite the limited acceptability ratings, the products could be consumed over a 4week period. However, the weight gain seen among all four subjects is disturbing. Although the discussion dismisses this finding by saying that it may reflect growth, the amounts of weight gain seen over 4 weeks were $0.4,1.7,1.9$ and $3.2 \mathrm{~kg}$. Certainly the latter three gains, if continued over a year, would be quite excessive. Given that the point of this dietary intervention is to prevent excessive weight gain, these preliminary findings are cause for considerable concern.

The authors have conducted a well-designed study of the feasibility of this innovative dietary intervention which has the purpose of obesity prevention. The findings show that it is possible to get children and adolescents to consume yogurt containing resistant starches, but more development is necessary to produce a food product with adequate acceptability. Aside from that, however, the assumption that this product, if consumed regularly, might avert excess weight gain needs further study, as the limited results here suggest its effect may be just the opposite of that which was expected and desired.

Competing Interests: No competing interests were disclosed.

I confirm that I have read this submission and believe that I have an appropriate level of expertise to confirm that it is of an acceptable scientific standard. 
The benefits of publishing with F1000Research:

- Your article is published within days, with no editorial bias

- You can publish traditional articles, null/negative results, case reports, data notes and more

- The peer review process is transparent and collaborative

- Your article is indexed in PubMed after passing peer review

- Dedicated customer support at every stage

For pre-submission enquiries, contact research@f1000.com 